\title{
Four new species of Dypsis (Arecaceae: Arecoideae) from Madagascar
}

\author{
Wolf L. Eiserhardt ${ }^{1,2}$, John Dransfield ${ }^{1}$, Mijoro Rakotoarinivo ${ }^{3}$ \& William J. Baker ${ }^{1}$
}

Summary. Four new palm species are described in the genus Dypsis: three tree palms from the Masoala peninsula in north-eastern Madagascar (D. mijoroana sp. nov., D. ovojavavy sp. nov. and D. rabepierrei sp. nov.), and one understorey palm, D. aurantiaca sp. nov. from eastern-central Madagascar. Illustrations, a distribution map and conservation status are provided for all four species.

Key Words. Areceae, Dypsidinae, Palmae, taxonomy.

\section{Introduction}

With 207 currently accepted native species, the palm flora of Madagascar is renowned for being much richer than the palm flora of its neighbour, the African continent, which harbours only 66 species (Couvreur 2015). It is also known for its extreme phylogenetic clustering (Kissling et al. 2012): more than three quarters of Madagascar's palms belong to a single subendemic genus, Dypsis Noronha ex Mart., while colonisation by other lineages has contributed little to the island's palm diversity.

Dypsis is a genus of great morphological diversity, ranging from delicate, almost grass-like understorey palms through lianas to massive emergent canopy palms (Dransfield \& Beentje 1995). The genus is most diverse in the humid rainforests of eastern Madagascar, although some species occur in drier and more seasonal habitats. Dypsis was treated comprehensively by Dransfield \& Beentje (1995), who accepted 140 species. However, numerous new species have been described since that monograph (Britt \& Dransfield 2005; Dransfield 2003; Dransfield et al. 2014; Dransfield \& Marcus 2002, 2013; Dransfield \& Rakotoarinivo 2012; Hodel \& Marcus 2004, Hodel et al. 2005, Hodel et al. 2009; Rakotoarinivo \& Dransfield 2010; Rakotoarinivo et al. 2009). Those new discoveries were largely the result of continuing fieldwork, and the rate of species discovery in Dypsis shows no signs of slowing down. This is unsurprising since many Dypsis species are range restricted, and numerous fragments of the once widespread humid forest of eastern Madagascar remain to be surveyed for palms. Unfortunately, mainly due to their narrow ranges and significant ongoing habitat transformation, most recently described species are also threatened with extinction (Rakotoarinivo et al. 2014).

Here we describe four new species that were discovered on field trips to palm-rich regions of eastern Madagascar (Map 1). The three tree palms, Dypsis mijoroana sp. nov., D. ovojavavy sp. nov., and D. rabepierrei sp. nov. were first discovered by one of us (JD) in 1996 on a brief expedition to the eastern side of the Masoala Peninsula (Dransfield 1996). JD recognised them as being undescribed; however, the material available for collection at that time, lacking flowers and fruit, was inadequate for the new species to be described. Other new discoveries from that expedition were described by Rakotoarinivo \& Dransfield (2010). In 2015, WLE, MR and WJB revisited the area to collect more material; a detailed description of this expedition and the palm flora of Masoala is given by Baker et al. 2016. The fourth species, D. aurantiaca sp. nov., was found by WLE and MR on a field trip to southern and eastern-central Madagascar in 2014. All four species are known only from very restricted areas around their respective type localities. Although the palms described from Masoala occur inside the Masoala National Park,

Accepted for publication 15 August 2018. Published online 1 October 2018

1 Royal Botanic Gardens, Kew, Richmond, Surrey, TW9 3AE, UK. e-mail: w.eiserhardt@kew.org

2 Department of Bioscience, Aarhus University, 8000, Aarhus C, Denmark.

3 Mention Biologie et Ecologie Végétales, Faculté des Sciences, Université d'Antananarivo, BP 906101, Antananarivo, Madagascar. 
ongoing forest clearing in both areas may pose a serious threat to all four species.

\section{Taxonomic Treatment}

1. Dypsis mijoroana Eiserhardt $\mathcal{E}$ W. J. Baker sp. nov. Type: Madagascar, Antsiranana, Sava, Antalaha, Vinanivao, Tanany Rabe Pierre (Ankorabe), $60 \mathrm{~m}$ a.s.l., $15^{\circ} 43^{\prime} 51^{\prime \prime S}, 50^{\circ} 12^{\prime} 55^{\prime \prime E}, 17$ Nov. 2015, Eiserhardt et al. 135 (holotype K!, isotypes MO!, P!, TAN!).

http://www.ipni.org/urn:lsid:ipni.org:names:77187266-1

Moderately robust solitary canopy palm to $15 \mathrm{~m}$, bearing 13 - 16 spirally arranged leaves in crown. Stem $15-20 \mathrm{~cm}$ in diam., unevenly columnar; leaf scars closely spaced and more prominent at stem apex; internodes $2-11 \mathrm{~cm}$ (to $20 \mathrm{~cm}$ in juveniles), greybrown with abundant lichen growth. Leaf $3.5-4 \mathrm{~m}$ long including petiole (to $6 \mathrm{~m}$ in juveniles); sheath short and open, $60-65 \mathrm{~cm}$ long, with abundant rusty red-brown lanate indumentum, with thinner greywhite indumentum beneath that extends throughout petiole and rachis, inner surface of sheath bright pinkred, crownshaft not well-defined, c. $130 \mathrm{~cm}$ long, c. $40 \mathrm{~cm}$ wide; petiole $60-70 \mathrm{~cm}$ long, concave on adaxial surface; leaflets 80 - 89 each side of rachis, mostly irregularly arranged in different planes and variously fascicled, but also regularly arranged in places (especially towards leaf apex), concolorous, with abundant ramenta distributed patchily along abaxial surface of midrib, especially dense near base, with smaller rusty brown scales on abaxial surface of margins and ribs; basal leaflets $66-110 \mathrm{~cm}$ long, 1.2 $1.6 \mathrm{~cm}$ wide, linear, single-fold, rein-like towards the apex; middle leaflets $77-84 \mathrm{~cm}$ long, $2.8-3.9 \mathrm{~cm}$ wide, linear, single-fold, transverse veinlets inconspicuous; apical leaflets $18-30 \mathrm{~cm}$ long, $1.5-2.2 \mathrm{~cm}$ wide, linear-lanceolate, not united, single- to 2-folded, usually with filiform vestigial extension of rachis to $24 \mathrm{~cm}$ extending between them. Inflorescence c. $2.5 \mathrm{~m}$ long, interfoliar, widely spreading, upright and arching, branched to $2-4$ orders, green, with redbrown indumentum as sheath on peduncle and rachis, becoming more sparse with subsequent orders of branching; prophyll $60-65 \mathrm{~cm}$ long, $8-15 \mathrm{~cm}$ wide, with red-brown indumentum as sheath; peduncular bract not seen; peduncle $100-110 \mathrm{~cm}$ long, c. $6 \mathrm{~cm}$ wide, ellipsoid in section; primary branches c. 32 , to c. $70 \mathrm{~cm}$ long; rachillae $28-45 \mathrm{~cm}$ long, $3.5-4.5 \mathrm{~mm}$ in diam.; rachilla bracts inconspicuous; triads $1.5-2 \mathrm{~mm}$ apart, spirally arranged, developing in shallow pits. Male flower $2.4-2.8 \mathrm{~mm}$ long, $1.9-2.4 \mathrm{~mm}$ in diam. in early bud, green; sepals 3, 1.5 - $1.9 \mathrm{~mm}$ long, 1.3 $1.6 \mathrm{~mm}$ wide, cucullate, glabrous; petals $1.6-1.8 \mathrm{~mm}$ long, $1.4-1.5 \mathrm{~mm}$ wide, rounded, glabrous; stamens
6; filaments $0.5-0.6 \mathrm{~mm}$ long, free, spindle-shaped; anthers 0.9 - $1.1 \mathrm{~mm}$ long, $0.4-0.5 \mathrm{~mm}$ wide, dorsifixed, dehiscence latrorse; pistillode 1.4 $1.6 \mathrm{~mm}$ long, c. $0.4 \mathrm{~mm}$ in diam (Fig. 1). Female flower not seen. Fruit not seen. Seed not seen.

RECOGNITION. This palm shares its characteristic rusty red-brown indumentum with Dypsis lastelliana (Baill.) Beentje \& J. Dransf. and D. leptocheilos (Hodel) Beentje \& J. Dransf., but is easily distinguished from those species by its plumose leaves.

DISTRIBUTION. Known only from the type locality on the eastern side of the Masoala peninsula (Madagascar). Map 1.

SPECIMENS EXAMINED. MADAGASCAR. Antsiranana: Sava, Antalaha, Vinanivao, Tanany Rabe Pierre (Ankorabe), $60 \mathrm{~m}$ a.s.l., $15^{\circ} 43^{\prime} 51^{\prime \prime S}, 50^{\circ} 12^{\prime} 55^{\prime \prime} \mathrm{E}, 17$ Nov. 2015, Eiserhardt et al. 135 (K!, MO!, P!, TAN!); Sava, Antalaha, Vinanivao, Masoala Peninsula, Tanany Rabe Pierre, $\mathrm{N}$ of Iketra, Ankorabe, $60 \mathrm{~m}$ a.s.l.,

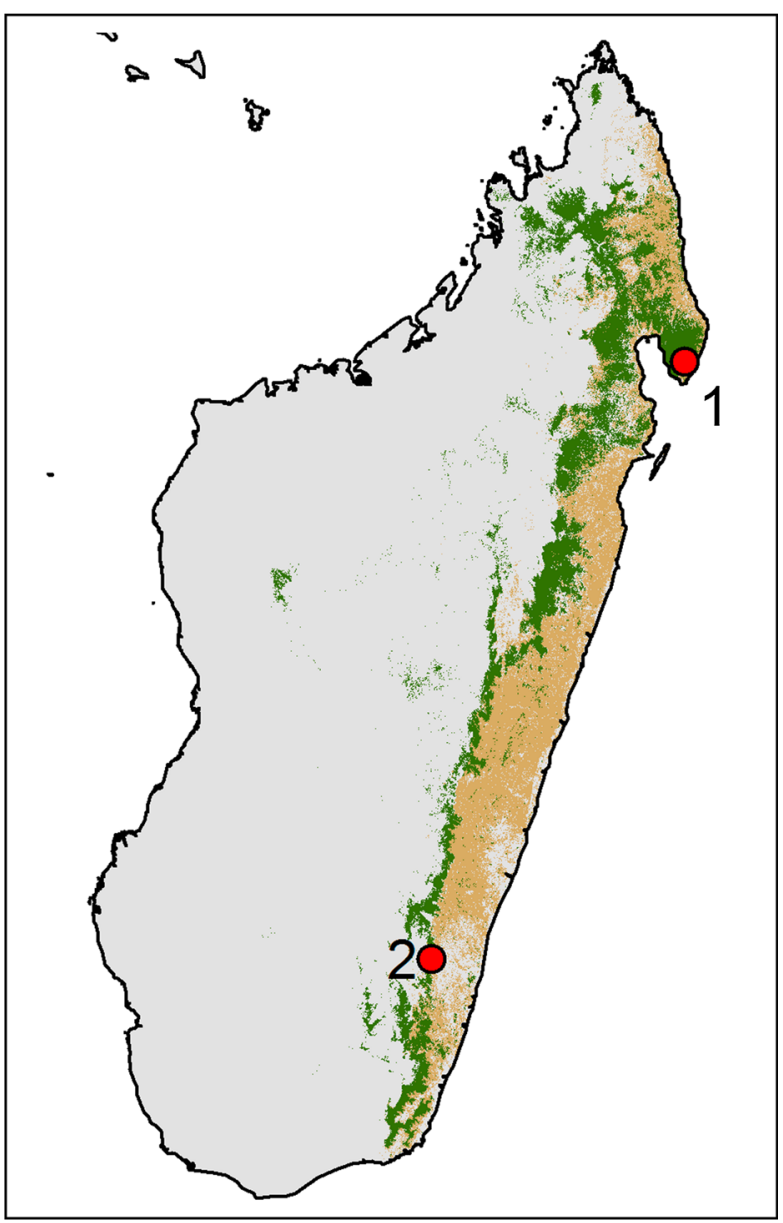

Map 1. Known distributions of the newly described species: Locality 1: Dypsis mijoroana, D. ovojavavy, D. rabepierrei. Locality 2: Dypsis aurantiaca. Humid forest in green, degraded humid forest in brown, other vegetation types in grey. Vegetation after Moat \& Smith (2007). 


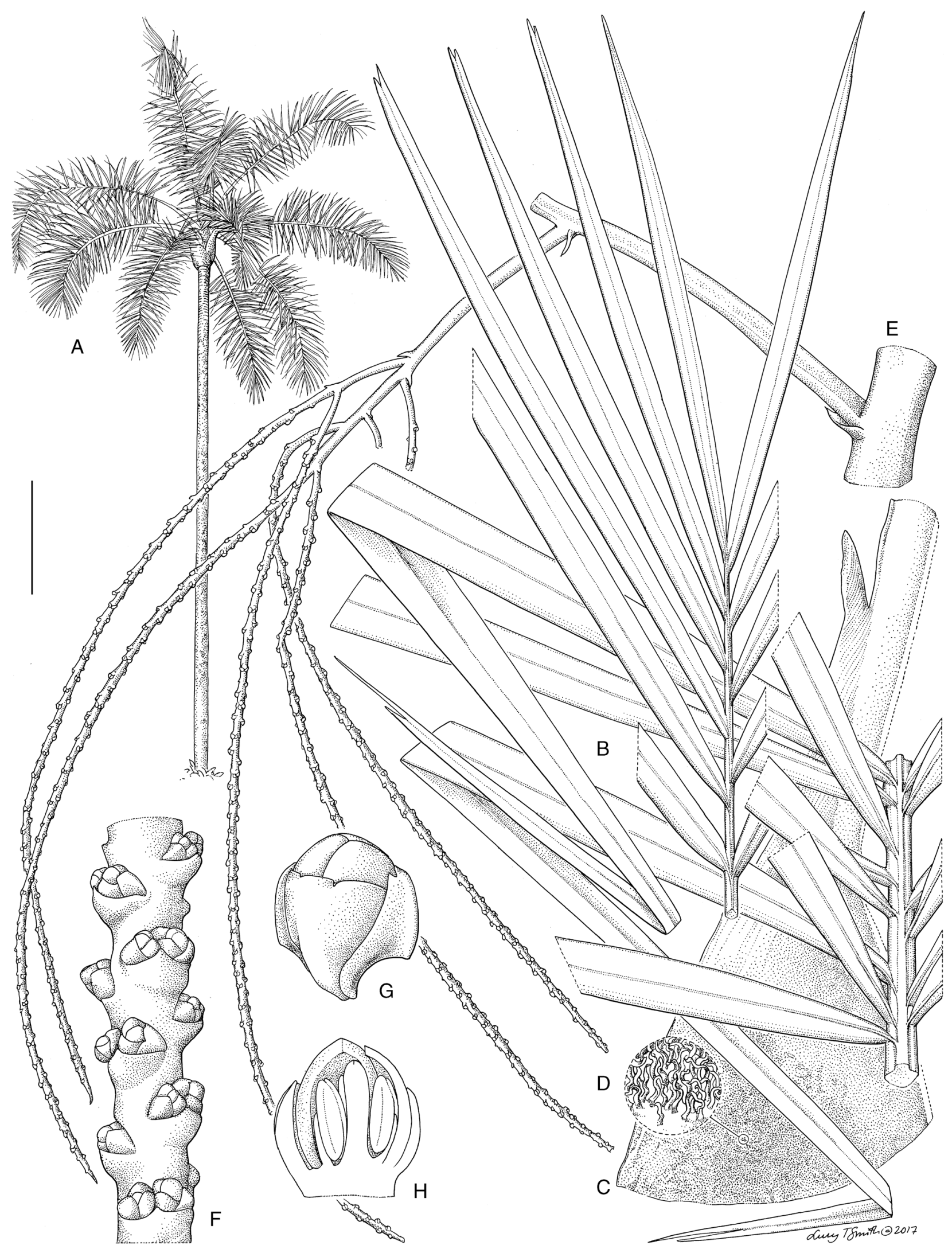

Fig. 1. Dypsis mijoroana. A habit; $B$ apical leaflets; $C$ leaf base; $D$ detail of indumenta on leaf base; $E$ partial inflorescence; $F$ flowers on rachilla; $\mathrm{G}$ male flower; $\mathrm{H}$ male flower in longitudinal section. Scale bar: $\mathrm{A}=2 \mathrm{~m} ; \mathrm{B}-\mathrm{C}, \mathrm{E}=6 \mathrm{~cm} ; \mathrm{D}=1.3 \mathrm{~mm} ; \mathrm{F}=5 \mathrm{~mm}$. All from Eiserhardt et al. 135. DRAWN BY LUCY T. SMITH. 


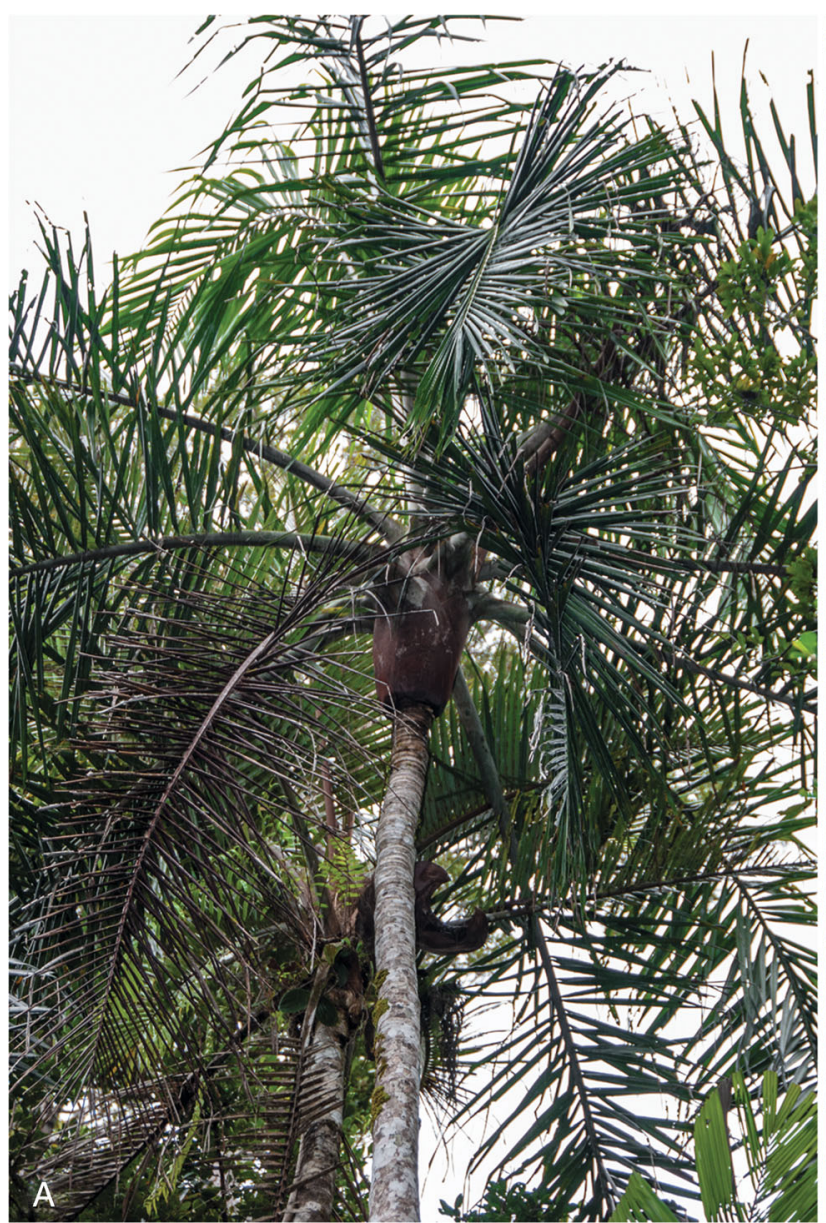

Fig. 2. Dypsis mijoroana. A habit; B crown shaft.

1543'51"S, 50²1'54"E, 17 Nov. 2015, Baker et al. 1418b (K!, MO!, P!, TAN!); Antalaha, Masoala Peninsula, Sahamalaza, Iketra, Tanany Rabepierre, $40 \mathrm{~m}$ a.s.l., $15^{\circ} 44$ 'S, 50¹3'E, Dransfield et al. 7639 (K!).

HABITAT. Primary lowland humid forest. Deep humus over white sand.

VERNACULAR NAMES AND USES. Sira, or sira-mafy (Betsimisaraka).

CONSERVATION STATUS. Critically Endangered (CR) [B2a,b (iii) $+\mathrm{D}]$. The known population is located in a forest fragment at the edge of the Masoala National Park, relatively close to human habitation. A decline in the quality of the habitat is predicted and this could impact on the long-term survival of this small population.

ETYMOLOGY. The species is named after Dr Mijoro "Joro" Rakotoarinivo, whose work has greatly improved our knowledge of Madagascan palm taxonomy, ecology and conservation.

NOTES. This palm is instantly recognisable by its gnarled appearance, with its somewhat irregular stem, poorly defined crownshaft and plumose leaves, as well as the abundant red-brown indumentum that covers the leaf sheath (Fig. 2). With its plumose leaves, open

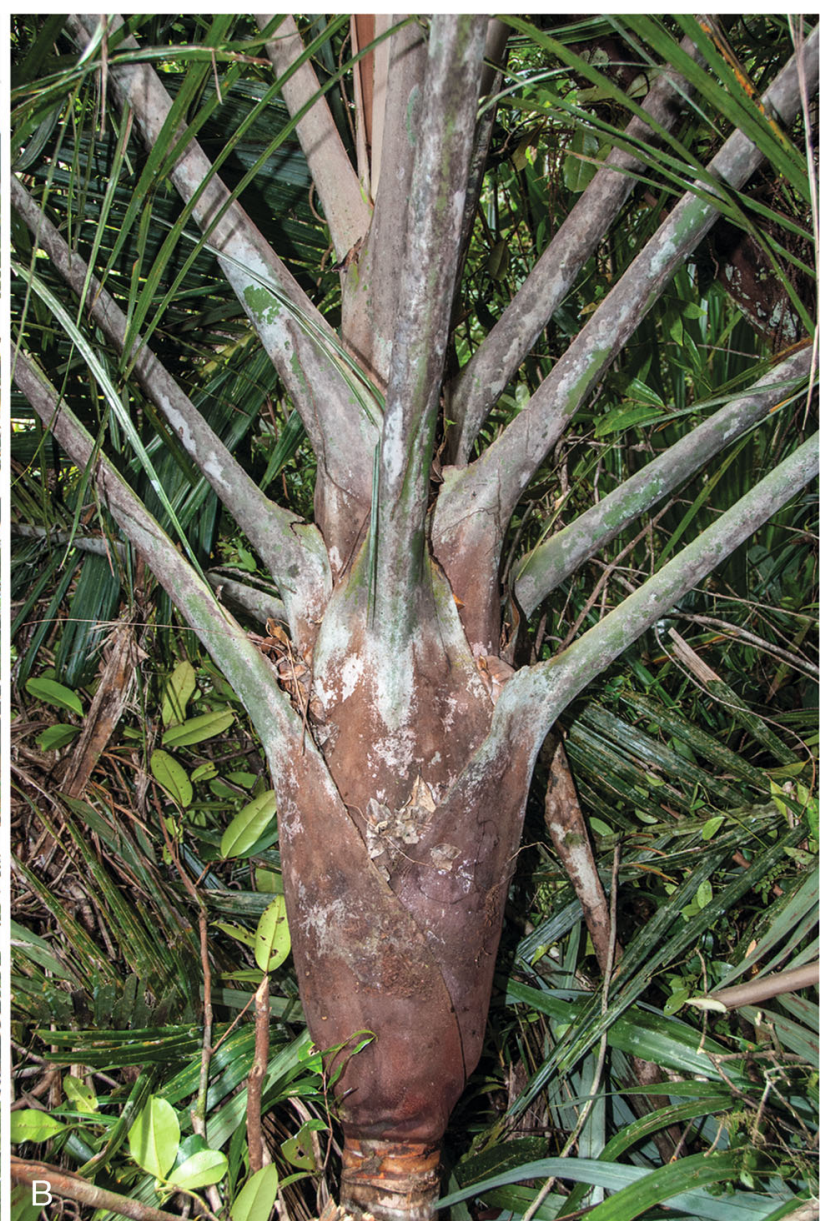

sheaths and spreading inflorescences with slender rachillae it is reminiscent of Dypsis tokoravina Beentje. This latter species is a gigantic palm, one of the largest in Madagascar, and certainly did not come to mind when we saw D. mijoroana in the field. Perhaps data from molecular analysis will indicate whether the two taxa are closely related or not. Dypsis mijoroana can be distinguished by its much smaller size, and the very dense red brown indumentum on the sheaths reminiscent of, for example, D. lastelliana. The inflorescence is substantially smaller than in $D$. tokoravina.

2. Dypsis ovojavavy Eiserhardt $\mathcal{E}^{\circ}$ W. J. Baker sp. nov. Type: Madagascar, Antsiranana, Vinanivao, Masoala Peninsula, Tanany Rabe Pierre, N of Iketra, Ankorabe, $60 \mathrm{~m}$ a.s.1., $15^{\circ} 43^{\prime} 51^{\prime \prime S}, 50^{\circ} 12^{\prime} 54^{\prime \prime E}, 17$ Nov. 2015, Baker et al. 1419 (holotype K!, isotypes MO!, P!, TAN!).

http:/ /www.ipni.org/urn:lsid:ipni.org:names:77187917-1

Moderate, solitary, mid-storey palm to at least $16 \mathrm{~m}$, bearing 8 spirally arranged leaves in crown. Stem 8 $9 \mathrm{~cm}$ in diam., green, becoming dull grey with age, 
smooth; leaf scars prominent; internodes $5-8 \mathrm{~cm}$. Leaf c. $275 \mathrm{~cm}$ long including petiole, erect and recurving; sheath c. $60 \mathrm{~cm}$ long, with acute auricles at the mouth, deeply split to two thirds of its length, pale green, yellow-orange near apex, with white bloom throughout, with patches of grey-white powdery caducous indumentum, forming crownshaft c. $90 \mathrm{~cm}$ long, c. $20 \mathrm{~cm}$ wide; petiole c. $35 \mathrm{~cm}$ long, concave on adaxial surface, pale green; leaflets 53 - 58 each side of rachis, stiffly ascending, regularly arranged in one plane on each side of the rachis, concolorous, abundant ramenta on abaxial surface of midrib; basal leaflets slightly grouped, $80-88 \mathrm{~cm}$ long, $1.5-2 \mathrm{~cm}$ wide, single fold, linear-lanceolate; middle leaflets 75 $77 \mathrm{~cm}$ long, 3.2 - $3.5 \mathrm{~cm}$ wide, linear-lanceolate, single fold, transverse veinlets inconspicuous; apical leaflets $31-33 \mathrm{~cm}$ long, $1.2-1.8 \mathrm{~cm}$ wide, linear, united c. $4 \mathrm{~cm}$ at base. Inflorescence c. $210 \mathrm{~cm}$ long, interfoliar, widely spreading, erect, becoming pendulous with age, branched to 3 orders; prophyll c. $60 \mathrm{~cm}$ long, c. $8 \mathrm{~cm}$ wide, hidden within leaf sheath, glabrous; peduncular bract attached c. $25 \mathrm{~cm}$ above prophyll; peduncle c. $120 \mathrm{~cm}$ long, c. $3 \mathrm{~cm}$ wide, glabrous; primary branches 29 , to $62 \mathrm{~cm}$ long, $4-5.5 \mathrm{~cm}$ apart, with up to 17 rachillae; rachillae $26-39 \mathrm{~cm}$ long, c. $5 \mathrm{~mm}$ in diam., tapering to $1-2 \mathrm{~mm}$; rachilla bracts inconspicuous; triads $0.6-0.7 \mathrm{~mm}$ apart, spirally arranged, flowers borne in pits. Male flower not seen. Female flower seen only at post-anthesis stage when forming young fruit, $3.9-4.2 \mathrm{~mm}$ long, $2.9-3.5 \mathrm{~mm}$ in diam., borne throughout the rachillae; sepals $3,1.8-2.2 \mathrm{~mm}$ long, $2-2.5 \mathrm{~mm}$ wide, cucullate; petals $3,2.2-2.8 \mathrm{~mm}$ long, 2.2 - $2.9 \mathrm{~mm}$ wide, acuminate; gynoecium (young fruit) c. $3.8 \mathrm{~mm}$ long, c. $2.5 \mathrm{~mm}$ in diam, ellipsoid; stigmatic remains basal (Fig. 3). Fruit not seen. Seed not seen.

RECOGNITION. This species is distinguished by its upright, arching leaves with stiffly erect leaflets (reminiscent of Dypsis baronii (Becc.) Beentje \& J. Dransf.) in combination with a large, spreading inflorescence and distinctive triangular auricles on the leaf sheaths.

DISTRIBUTION. Known only from the type locality on the eastern side of the Masoala peninsula (Madagascar). Map 1.

SPECIMENS EXAMINED. MADAGASCAR. Antsiranana: Vinanivao, Masoala Peninsula, Tanany Rabe Pierre, N of Iketra, Ankorabe, $60 \mathrm{~m}$ a.s.1., 15 43'51"S, 50²'54"E, 17 Nov. 2015, Baker et al. 1419 (K!, MO!, P!, TAN!).

HABITAT. Primary lowland humid forest. Deep humus over white sand.

VERNACULAR NAMES AND USES. Ovojavavy (Betsimisaraka).

CONSERVATION STATUS. Critically Endangered (CR) [B2a,b (iii)+D]. The only known population is record- ed from a forest fragment at the edge of the Masoala National Park where human settlement occurs. A decline in the quality of the habitat will lead to the disturbance of the long-term survival of the remaining population and may thus increase the extinction risk of this species.

ETYMOLOGY. The epithet is derived from the vernacular name locally applied to the palm, ovojavavy (pronounced "oov-jah-vav"). Ovojavavy is a compound word consisting of hovotra (palm heart) and zavavy (young girl), meaning "girl's palm".

NOTES. Dypsis ovojavavy is an elegant, moderately robust, mid-storey tree palm with stiffly ascending leaflets. The inflorescence is interfoliar, rather large and pendulous at later stages of development. Its crownshaft is also distinctive, being composed of pale green leaf sheaths, tinged with orange-yellow and with a white bloom throughout, and triangular auricles at the apex (Fig. 4). It clearly belongs to the informal Group 3 of Dransfield \& Beentje (1995) where it is distinctive in its solitary habit, large spreading inflorescence and, most particularly by the crowded stiff ascending leaflets. Delineation of species in this group has proved to be problematic, with great variation within already described taxa (such as D. lutescens $(\mathrm{H}$. Wendl.) Beentje \& J. Dransf. and D. baronii), but nevertheless, D. ovojavavy does not fit any already described taxon.

3. Dypsis rabepierrei Eiserhardt $\mathcal{E}$ W. J. Baker sp. nov. Type: Madagascar, Antsiranana, Sava, Antalaha, Vinanivao, Tanany Rabepierre (Ankorabe), $74 \mathrm{~m}$ a.s.l., $15^{\circ} 43^{\prime} 41^{\prime \prime S}, 50^{\circ} 12^{\prime} 50^{\prime \prime E}, 18$ Nov. 2015, Eiserhardt et al. 138 (holotype K!, isotypes MO!, P!, TAN!).

http://www.ipni.org/urn:lsid:ipni.org:names:60476871-2

Slender, solitary, mid-storey palm $4-6 \mathrm{~m}$ tall (rarely to $20 \mathrm{~m}$ ), bearing $6-10$ spirally arranged leaves in crown. Stem $2.5-7 \mathrm{~cm}$ in diam., green; leaf scars prominent; internodes $1.5-10 \mathrm{~cm}$; covered in white indumentum. Leaf to $250 \mathrm{~cm}$ long including petiole; sheath $35-60 \mathrm{~cm}$ long, blackish green with white indumentum, apically also with blackish-brown scales, young sheaths bright red, crownshaft to $70 \mathrm{~cm}$ long, $4-5 \mathrm{~cm}$ wide; petiole $41-70 \mathrm{~cm}$ long, concave on adaxial surface, green, basal portion sparsely covered with blackish-brown, peltate scales; leaflets 33 - 45 each side of rachis, regularly arranged in one horizontal plane, slightly arching, borne $0.5-5 \mathrm{~cm}$ apart, adaxially glaucous and abaxially reddish brown when dry, glaucous on adaxial surface; basal leaflets $35-56 \mathrm{~cm}$ long, 0.6 $1.1 \mathrm{~cm}$ wide, linear; middle leaflets $43-61 \mathrm{~cm}$ long, $1.2-1.6 \mathrm{~cm}$ wide, linear, transverse veinlets inconspicuous; apical leaflets $12-17 \mathrm{~cm}$ long, $0.4-0.6 \mathrm{~cm}$ 


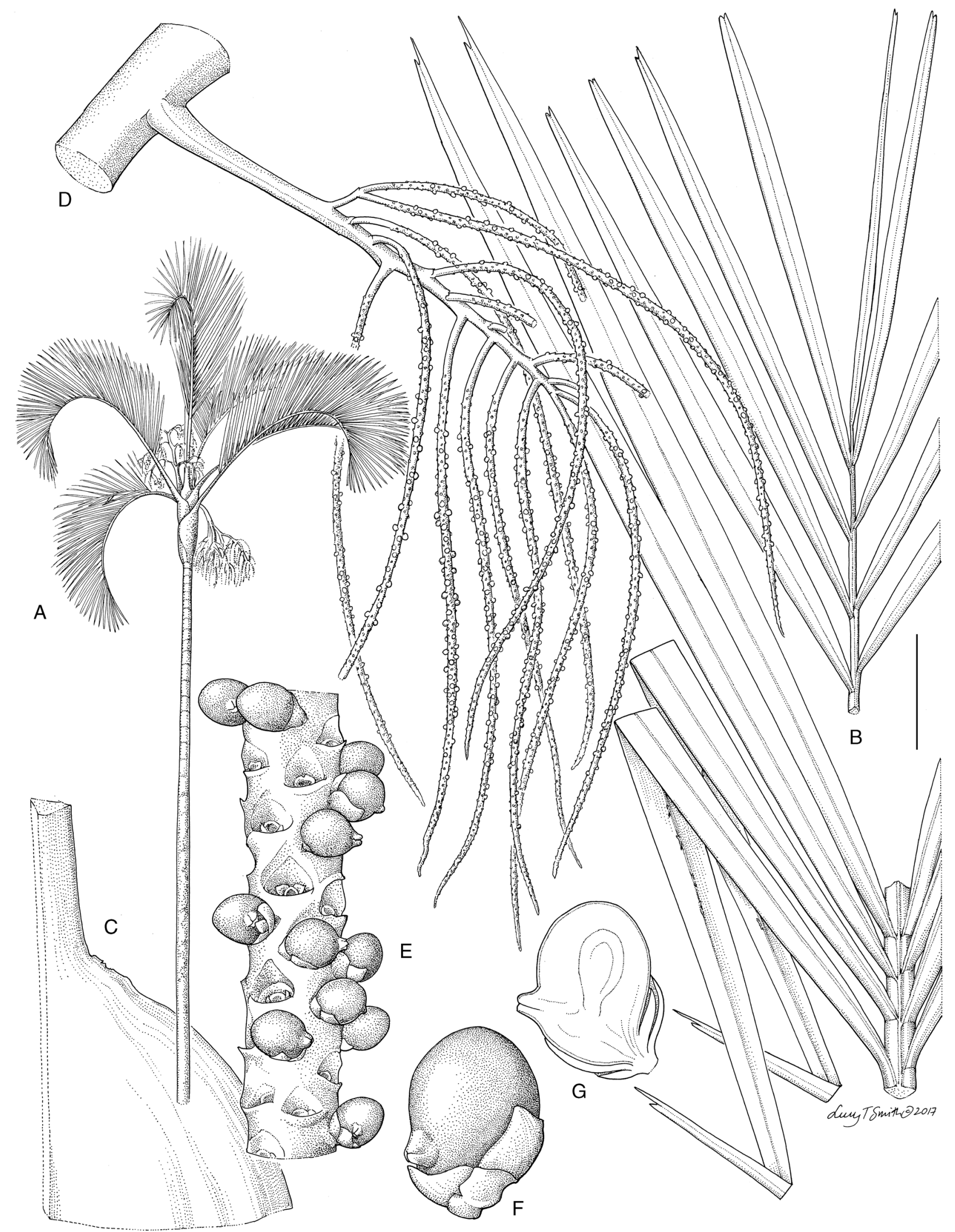

Fig. 3. Dypsis ovojavavy. A habit; B middle and apical leaflets; C leaf base; D partial inflorescence; E rachilla with developing fruits; $F$ young fruit; $G$ young fruit in longitudinal section. Scale bar: $A=90 \mathrm{~cm} ; B-C=8 \mathrm{~cm} ; D=6 \mathrm{~cm} ; E=7 \mathrm{~mm} ; F-G=2.5 \mathrm{~mm}$. All from Baker et al. 1419. DRAWN BY LUCY T. SMITH. 


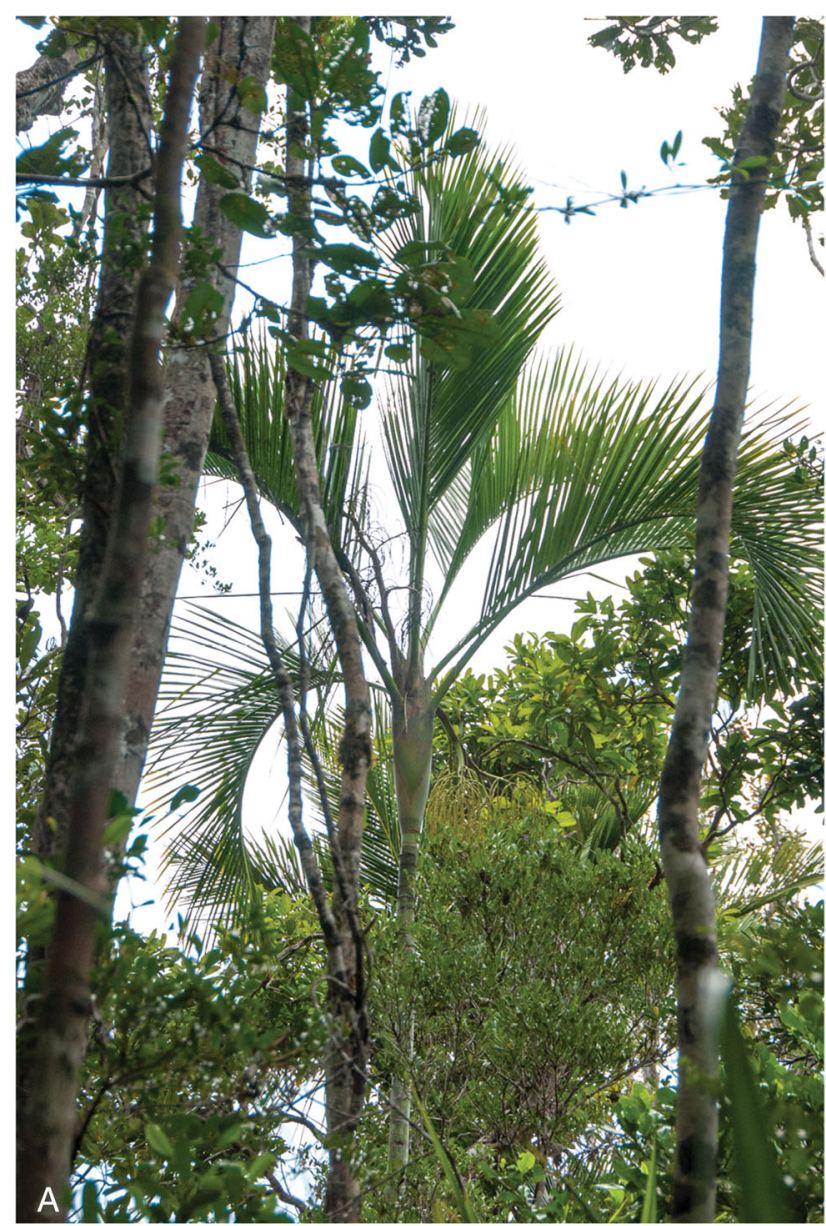

Fig. 4. Dypsis ovojavavy. A habit; B crown with inflorescence.

wide, linear, not united. Inflorescence 70 - $90 \mathrm{~cm}$ long, interfoliar, more or less horizontal, tassel-shaped, branched to 2 orders, pale yellow; prophyll 50 $62 \mathrm{~cm}$ long, $5-12 \mathrm{~cm}$ wide, green turning pale brown at anthesis, cucullate, glabrous; first peduncular bract similar to prophyll, persistent, c. $45 \mathrm{~cm}$ long, c. $10 \mathrm{~cm}$ wide, attached $6-7 \mathrm{~cm}$ below first primary branch; two additional inconspicuous peduncular bracts present, $0.3-1 \mathrm{~cm}$ long; peduncle $42-45 \mathrm{~cm}$ long, $1-2 \mathrm{~cm}$ wide, glabrous; primary branches c. 20 , to $18 \mathrm{~cm}$ long, c. $0.5 \mathrm{~cm}$ apart, with up to 8 rachillae; rachillae $8-15.5 \mathrm{~cm}$ long, $1.5-$ $3 \mathrm{~mm}$ in diam.; rachilla bracts inconspicuous; triads c. $2 \mathrm{~mm}$ apart, spirally arranged. Male flower 3.9 $4.4 \mathrm{~mm}$ long, $3.2-3.4 \mathrm{~mm}$ in diam. at anthesis; sepals 3, $1.8-2.3 \mathrm{~mm}$ long, $1.8-2 \mathrm{~mm}$ wide, cucullate with sharp keel; petals 2.5 - $3.2 \mathrm{~mm}$ long, $2.5-2.8 \mathrm{~mm}$ wide, rounded; stamens 6 ; filaments 1.9 - $2.5 \mathrm{~mm}$ long, free, spindle-shaped; undehisced anthers 2 - $2.2 \mathrm{~mm}$ long, c. $0.9 \mathrm{~mm}$ wide; dorsifixed; dehiscence latrorse; connective dark brown; pistillode $2.8-2.9 \mathrm{~mm}$ long, $0.9-1.1 \mathrm{~mm}$ in diam. at base, bottle-shaped, dark brown (Fig. 5). Female flower not seen. Fruit not seen. Seed not seen.

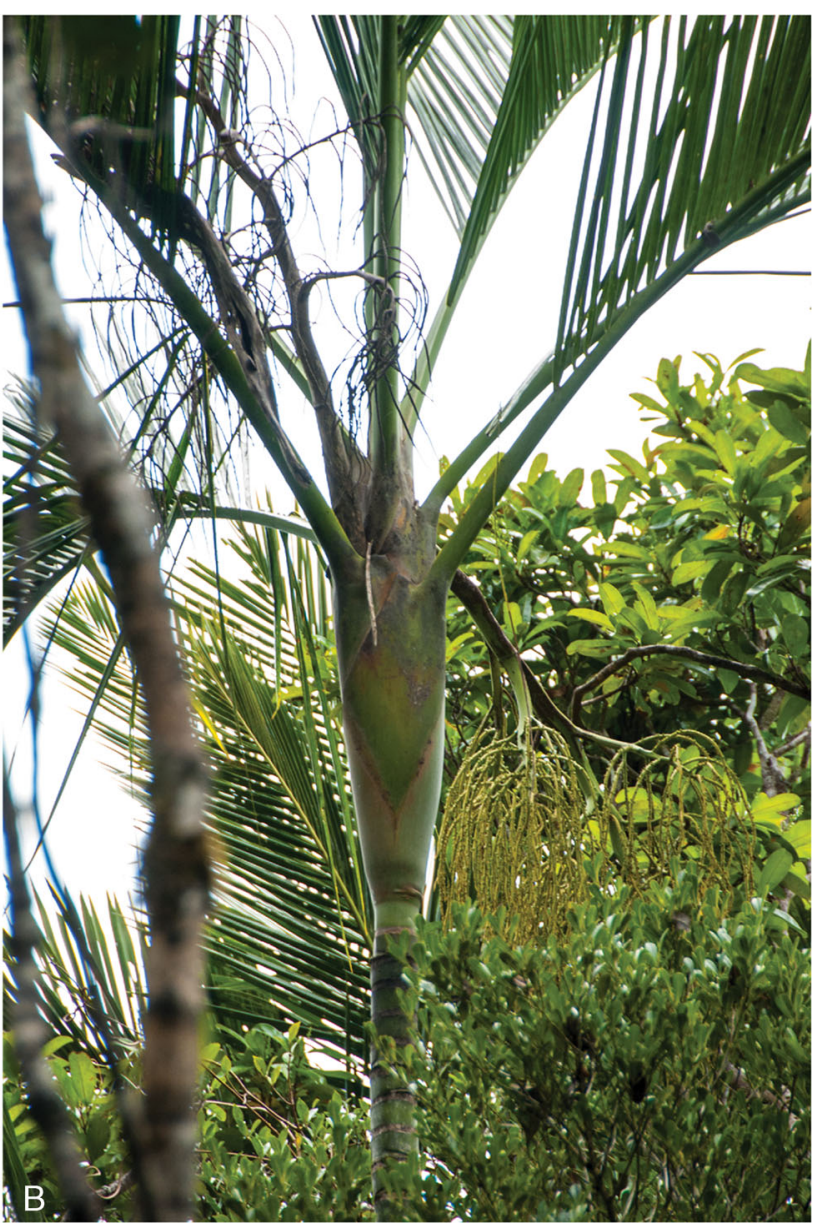

RECOGNITION. This palm is distinct from other Dypsis species in Group 3 sensu Dransfield \& Beentje (1995) being solitary, having a tassel-shaped inflorescence with prophyll and peduncular bract of very similar appearance and length, and glabrous leaflets.

DISTRIBUTION. Known only from the type locality and nearby places on the eastern side of the Masoala peninsula (Madagascar). Map 1.

SPECIMENS EXAMINED. MADAGASCAR. Antsiranana: Sava, Antalaha, Vinanivao, path from Anovandrano R., W of Iketra, $58.4 \mathrm{~m}$ a.s.1., $15^{\circ} 44^{\prime} 48^{\prime \prime S}, 50^{\circ} 10^{\prime} 58^{\prime \prime} \mathrm{E}, 15$ Nov. 2015, Eiserhardt et al. 128 (K!, MO!, TAN!); Sava, Antalaha, Vinanivao, Tanany Rabepierre (Ankorabe), $75 \mathrm{~m}$ a.s.1., $15^{\circ} 43^{\prime} 41^{\prime \prime S}$, 50²' $12^{\prime} 50^{\prime \prime E}, 18$ Nov. 2015, Eiserhardt et al. 137 (K!, MO!, P!, TAN!); Sava, Antalaha, Vinanivao, Tanany Rabepierre (Ankorabe), $74 \mathrm{~m}$ a.s.l., $15^{\circ} 43^{\prime} 41^{\prime \prime S}$, 50²' $12^{\prime} 50^{\prime \prime E}, 18$ Nov. 2015, Eiserhardt et al. 138 (K!, MO!, P!, TAN!); Sava, Antalaha, Vinanivao, Tanany Rabepierre (Ankorabe), $74 \mathrm{~m}$ a.s.l., 15²4'41"S, 50²' $50^{\prime}$ ", 18 Nov. 2015, Eiserhardt et al. 139 (K!, MO!, P!, TAN!); Antalaha, Masoala Peninsula, Sahamalaza, Iketra, Tanany Fred, $55 \mathrm{~m}$ a.s.1., $15^{\circ} 45^{\prime} \mathrm{S}, 50^{\circ} 12^{\prime} \mathrm{E}$, Dransfield et al. 7635 (K!). HABITAT. Primary lowland humid forest. 


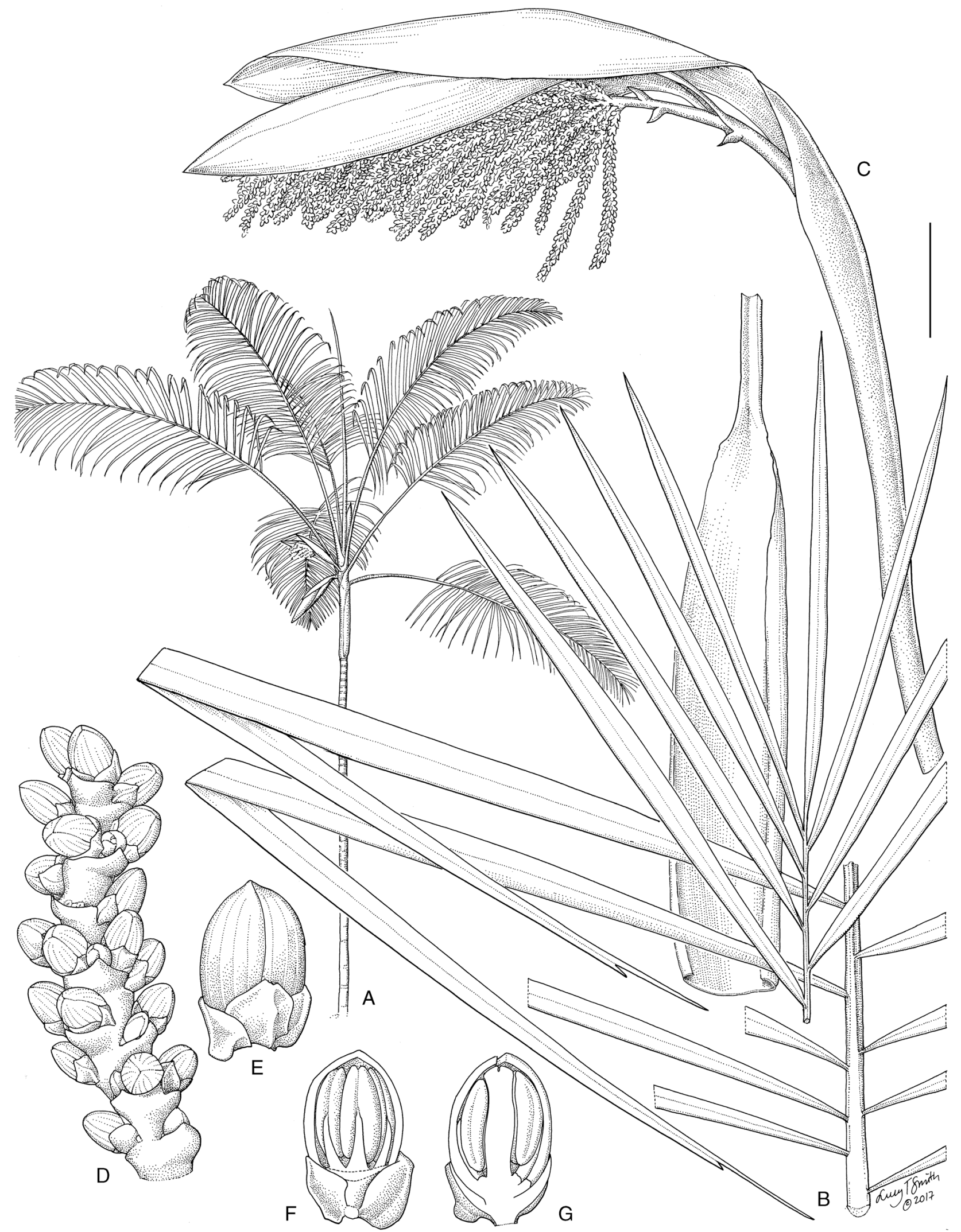

Fig. 5. Dypsis rabepierrei. A habit; $B$ middle and apical leaflets; $C$ inflorescence; $D$ triads on rachilla; $E$ male bud; $F$ male bud, petal removed; $G$ male bud in longitudinal section. Scale bar: $A=45 \mathrm{~cm} ; B=4 \mathrm{~cm} ; C=6 \mathrm{~cm} ; D=6.5 \mathrm{~mm} ; E-G=2.5 \mathrm{~mm}$. All from Eiserhardt et al. 128. DRAWN BY LUCY T. SMITH. 

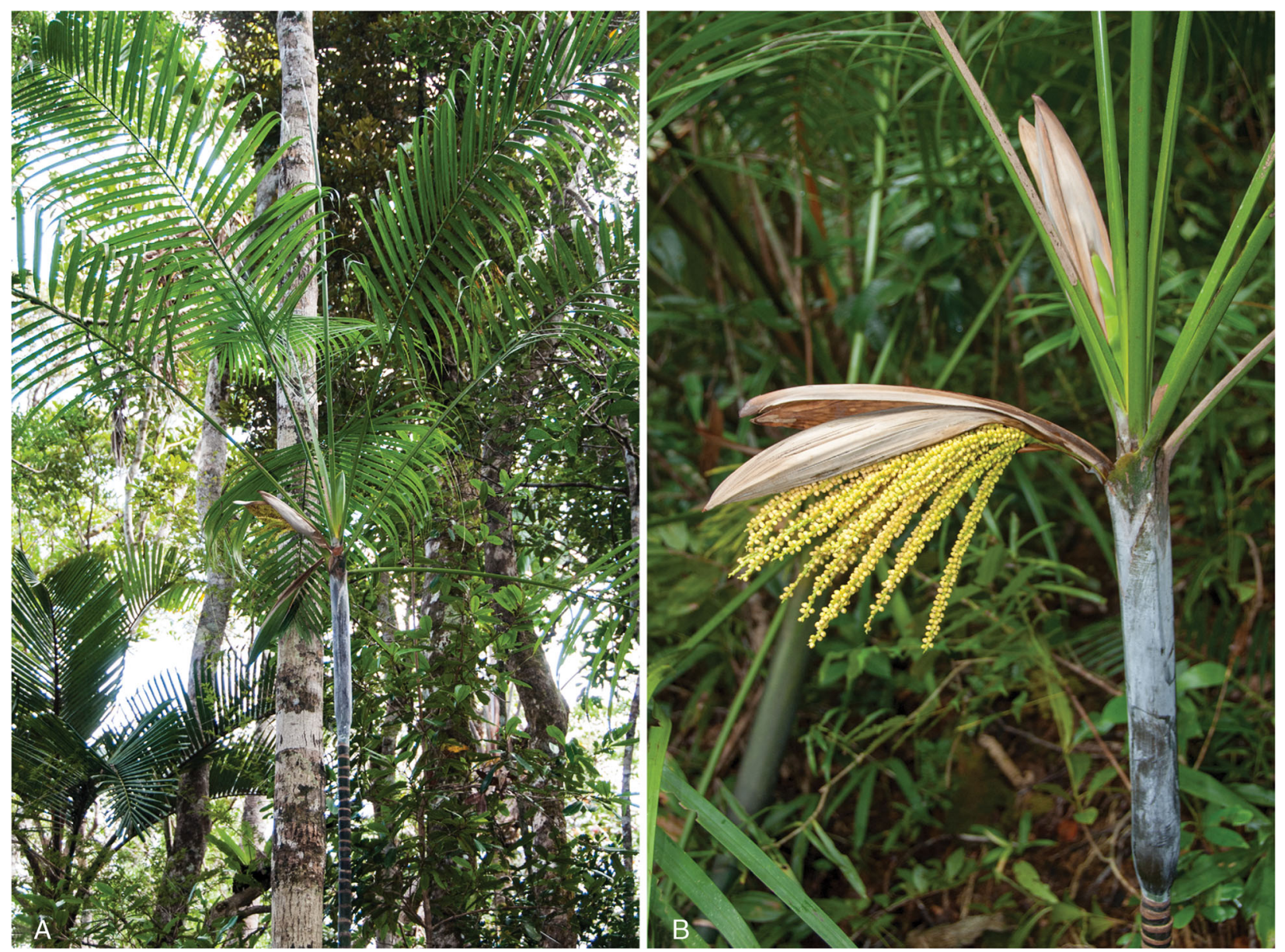

Fig. 6. Dypsis rabepierrei. A habit; B crown shaft and inflorescence.

VERNACULAR NAMES AND USES. Lafaza maitso or ovojavavy (Betsimisaraka).

CONSERVATION STATUS. Critically Endangered (CR)

$[\mathrm{B} 2 \mathrm{a}, \mathrm{b}(\mathrm{iii})+\mathrm{D}]$. The only known population is located at the edge of the Masoala National Park where the local population has some access to the natural resources. It is predicted that the quality of the habitat declines and may affect the long-term survival of the less than 20 individuals seen.

ETYMOLOGY. The species is named after Monsieur Rabe Pierre who kindly allowed us access to his land both in 1996 and 2015, guiding both expedition parties to palm-rich areas from which the type specimens of Dypsis rabepierrei, D. ovojavavy (both described here), D. metallica Rakotoarin. \& J. Dransf. and D. vonitrandambo Rakotoarin. \& J. Dransf. (Rakotoarinivo \& Dransfield 2010) were collected.

NOTES. This is a fairly inconspicuous medium-sized understory palm, the most outstanding feature being the intensely waxy-white crownshaft, and the tasselshaped yellow inflorescence with long cucullate prophyll and peduncular bract (Fig. 6). On morphological grounds its relationships lie with informal
Group 3 of Dransfield \& Beentje (1995) where it superficially resembles a single-stemmed form of Dypsis onilahensis (Jum. \& H. Perrier) Beentje \& J. Dransf., or D. baronii, but is immediately set apart by the unusual tassel-shaped inflorescence.

These relationships are confirmed by preliminary phylogenetic analyses (Eiserhardt \& Baker, unpublished data) that indicate affinity with Dypsis lutescens and D. arenarum (Jum.) Beentje \& J. Dransf. of coastal white sand forests.

4. Dypsis aurantiaca Eiserhardt $\mathcal{E}$ Rakotoarin. sp. nov. Type: Madagascar, Fianarantsoa, Atsimo-Atsinana, Vondrozo, Manambidala, on the road from Farafangana to Ihosy, W of Vondrozo, $598 \mathrm{~m}$ a.s.l.,

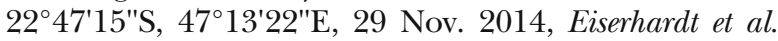
106 (holotype: $\mathrm{K}$ !, isotypes MO!, P!, TAN!).

http:/ / www.ipni.org/urn:Isid:ipni.org:names:60476872-2

Slender, clustering, undestory palm to $1.3 \mathrm{~m}$, bearing c. 6 spirally arranged leaves per crown. Stem c. $1.3 \mathrm{~cm}$ 


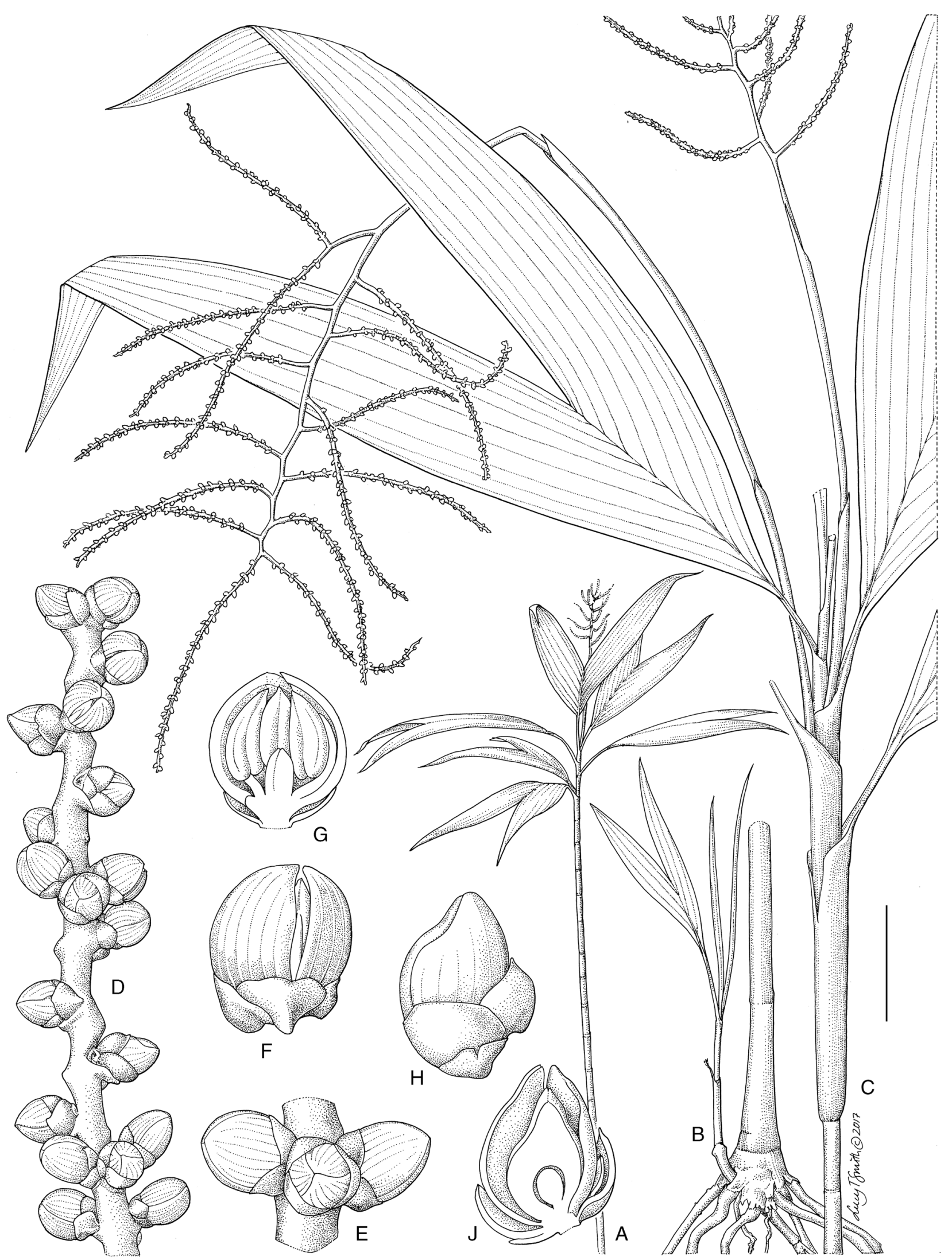

Fig. 7. Dypsis aurantiaca. A habit; $B$ stem base and young shoot; $C$ crown with inflorescences; $D$ triads on rachilla; $E$ triad; $F$ male bud; $\mathbf{G}$ male bud in longitudinal section; $\mathrm{H}$ female bud; J female bud in longitudinal section. Scale bar: $A=12 \mathrm{~cm} ; \mathrm{B}-\mathrm{C}=4 \mathrm{~cm}$; $\mathrm{D}$ $=4 \mathrm{~mm} ; \mathrm{E}=2.2 \mathrm{~mm} ; \mathrm{F}-\mathrm{J}=1.5 \mathrm{~mm}$. All from Eiserhardt et al. 106. DRAWN BY LUCY T. SMITH. 


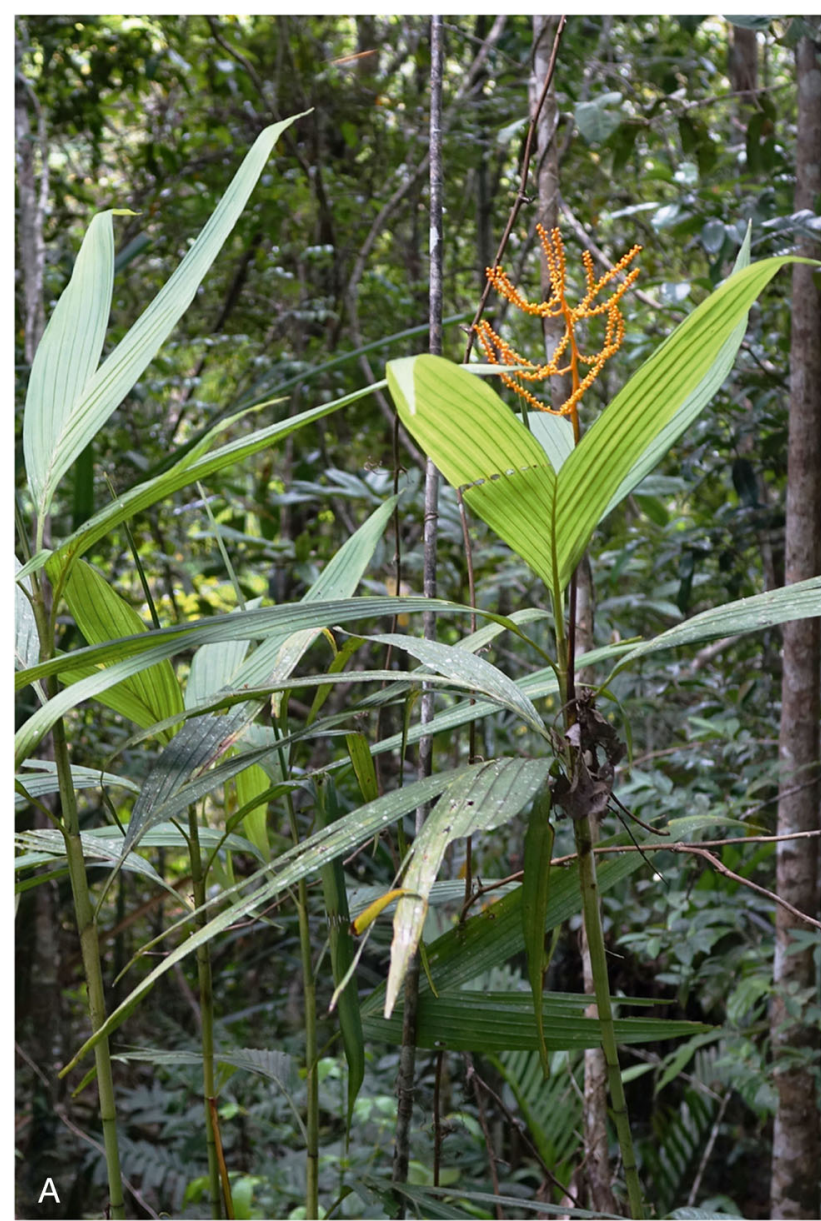

Fig. 8. Dypsis aurantiaca. A habit; B crown with inflorescence.

in diam. at base, green; leaf scars inconspicuous; internodes c. $4 \mathrm{~cm}$; surface dull brown when dry. Leaf bifid, to $42 \mathrm{~cm}$ long including c. $2 \mathrm{~cm}$ petiole, $13.5-$ $18 \mathrm{~cm}$ wide; sheath $10-12.5 \mathrm{~cm}$ long, bright green, forming a crownshaft, sparsely but evenly covered in glossy dark brown fimbriate scales; rachis $10-11 \mathrm{~cm}$ long; lamina glabrous; lobes $23-38.5 \mathrm{~cm}$ long, 2.8 $4.6 \mathrm{~cm}$ wide, 8 -folded, tips acute; transverse veinlets inconspicuous. Inflorescence $52-74 \mathrm{~cm}$ long, interfoliar, branched to 2 orders, erect, spreading, bright orange, all parts with glossy dark brown fimbriate scales; prophyll $14-16 \mathrm{~cm}$ long, $0.4-$ $0.6 \mathrm{~cm}$ wide, tightly sheathing, open for $1-1.5 \mathrm{~cm}$ at the apex; peduncular bract $25.5-28.5 \mathrm{~cm}$ long, $0.4-$ $0.6 \mathrm{~cm}$ wide, tightly sheathing, open for $2.5-5 \mathrm{~cm}$ at the apex, attached $10-11 \mathrm{~cm}$ above the base of the prophyll; peduncle $36-52 \mathrm{~cm}$ long, $0.2-0.3 \mathrm{~cm}$ wide; primary branches $10-16$, to $12 \mathrm{~cm}$ long, $0.3-2.2 \mathrm{~cm}$ apart, with up to 2 rachillae; rachillae $3-10 \mathrm{~cm}$ long, c. $0.5 \mathrm{~mm}$ in diam., triads c. $2 \mathrm{~mm}$ apart, spirally arranged. Male flower $1.6-2.2 \mathrm{~mm}$ long, $1.3-1.5 \mathrm{~mm}$ in diam.; sepals 3, c. $0.9 \mathrm{~mm}$ long, $0.9-1.1 \mathrm{~mm}$ wide, cucullate; petals $1.5-1.9 \mathrm{~mm}$ long, $1-1.3 \mathrm{~mm}$ wide,

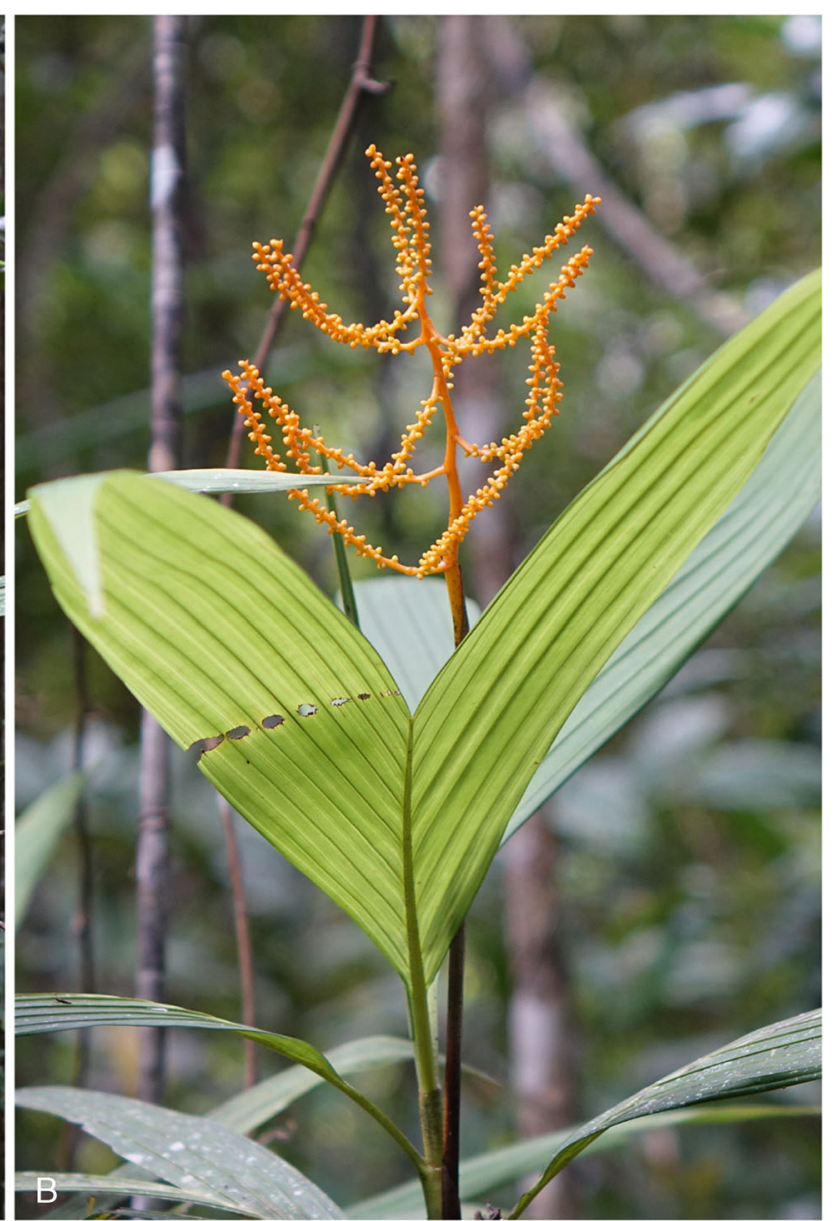

rounded; stamens 6 ; filaments $0.5-0.8 \mathrm{~mm}$ long, free, spindle-shaped, dark brown; anthers $1-1.3 \mathrm{~mm}$ long, $0.4-0.5 \mathrm{~mm}$ wide, pale, dorsifixed, dehiscence latrorse, connective dark brown with pointed tip extending beyond thecae at apex; pistillode 0.6 $0.8 \mathrm{~mm}$ long, $0.3-0.4 \mathrm{~mm}$ in diam., cylindrical with three furrows, dark brown. Female flowers borne throughout the rachillae, at the time of male anthesis $0.6-0.8 \mathrm{~mm}$ long, c. $0.6 \mathrm{~mm}$ in diam.; sepals 3, c. $0.6 \mathrm{~mm}$ long, c. $0.8 \mathrm{~mm}$ wide, cucullate; petals 3 , c. $0.8 \mathrm{~mm}$ long, c. $0.5 \mathrm{~mm}$ wide, rounded, dark brown; gynoecium c. $0.6 \mathrm{~mm}$ long, $0.4 \mathrm{~mm}$ in diam, dark brown (Fig. 7). Fruit not seen. Seed not seen.

RECOGNITION. This clustering understory palmlet is distinct in having broad, deeply bifid leaves and an erect, bright-orange inflorescence that protrudes above the leaves.

DISTRIBUTION. Known only from the type locality near Vondrozo on the eastern escarpment of Madagascar. Map 1.

SPECIMENS EXAMINED. MADAGASCAR: Fianarantsoa, Atsimo-Atsinana, Vondrozo, Manambidala, on the 
road from Farafangana to Ihosy, W of Vondrozo, 598 $\mathrm{m}$ a.s.1., 22 $47^{\prime} 15^{\prime \prime S}, 47^{\circ} 13^{\prime} 22^{\prime \prime E}, 29$ Nov. 2014, Eiserhardt et al. 106 (K!, MO!, P!, TAN!).

HABITAT. Primary lower montane forest. VERNACULAR NAMES AND USES. None known. CONSERVATION STATUS. Data deficient (DD). Only few clumps of this species have been seen on a hill relatively far from human habitation but along the main road. The DD category reflects here the lack of biological and ecological knowledge about this rare species; further investigation on its local distribution pattern and its threats should be undertaken.

NOTES. A delicate understory palm with a striking erect, bright orange inflorescence (Fig. 8). It belongs to the informal Group 8, that includes dwarf palms of the forest undergrowth with sparsely branched inflorescences and male flowers with six stamens, species formerly included in the genus Neophloga Baill. Most of these species have variously pinnate leaves, although Dypsis schatzii Beentje is almost always entireleaved and entire-leaved forms of D. concinna Baker and D. heterophylla Baker are occasionally found. Yet none of these taxa has the striking erect orange inflorescences of D. aurantiaca. In Dransfield \& Beentje (1995), this species keys to D. concinna (which has inconspicuous green inflorescences) or D. betamponensis (which has didymous stamens).

\section{Acknowledgements}

We are grateful to two anonymous reviewers for their insightful comments on the manuscript. We thank the Kew Madagascar Conservation Centre (especially Stuart Cable and Hélène Ralimanana) for help with organising fieldwork, and Andoniaina Z. Andriamanantena, Romer N. Rabarijaona, Linah Rabarivola, Roger Rajaonarison, Landy Rajaovelona, Franck Rakotonasolo and Solo H. J. V. Rapanarivo for their help and good company in the field. This work was funded by the European Union FP7-People programme (grant \#327259 to WLE). Fieldwork was funded by the National Geographic Society - Global Exploration Fund Northern Europe (grant GEFNE125-14), the International Palm Society, the Royal Horticultural Society, the Bentham-Moxon Trust, the Lord Faringdon Charitable Trust, and generous donations by Pam Le Couteur. We are grateful to the ministry of the environment of Madagascar (Ministère de l'Environnement, de l'Ecologie et des Forêts) for issuing collection permits No. 260/14 and No. 061/15 which made this work possible.

Open Access This article is distributed under the terms of the Creative Commons Attribution 4.0 International License (http://creativecommons.org/ licenses/by/4.0/), which permits unrestricted use, distribution, and reproduction in any medium, provided you give appropriate credit to the original author(s) and the source, provide a link to the Creative Commons license, and indicate if changes were made.

\section{References}

Baker, W. J., Eiserhardt, W. L., Rakotoarinivo, M., Andriamanantena, A. Z., Rabarijaona, R. N. \& Rapanarivo, S. H. J. V. (2016). The palms of the Masoala Peninsula. PALMS 60: 169 - 193.

Britt, A. \& Dransfield, J. (2005). Dypsis delicatula. PALMS 49: 40 - 44.

Couvreur, T. L. P. (2015). Odd man out: why are there fewer plant species in African rain forests? Pl. Syst. Evol. 301: 1299 - 1313.

Dransfield, J. (1996). Palms in Masoala: report of fieldwork in November 1996. Technical report. (2003). Dypsis turkii. PALMS 47: 26 - 30.

\& Beentje, H. (1995). The Palms of Madagascar. Royal Botanic Gardens Kew and the International Palm Society.

Hodel, D. R. \& Marcus, J. (2014). Dypsis rosea. PALMS 58: 181 - 185.

\& Marcus, J. (2002). Dypsis 'stumpy'. PALMS 46 : $47-51$.

\& __(2013). Dypsis leucomalla, a new species described from cultivation from Hawai'i. PALMS 57: 199 - 203.

\& Rakotoarinivo, M. (2012). The Palms of Tsitongambarika, Southeast Madagascar. PALMS 56: $161-179$.

Hodel, D. R. \& Marcus, J. (2004). The white powder Dypsis: a new species from cultivation. PALMS 48: 90 - 93.

\& Dransfield, J. (2005). Dypsis robusta, a large new palm from cultivation. PALMS 49: 128 - 130. \& _ (2009). Dypsis plumosa, the Madagascar queen palm. PALMS 53: 161 - 165.

Kissling, W. D., Eiserhardt, W. L., Baker, W. J., Borchsenius, F., Couvreur, T. L. P., Balslev, H. \& Svenning, J. C. (2012). Cenozoic imprints on the phylogenetic structure of palm species assemblages worldwide. Proc. Natl. Acad. Sci. U.S.A. 109: 7379 - 7384.

Moat, J. \& Smith, P. (2007). Atlas of the Vegetation of Madagascar. Kew Publishing, Richmond.

Rakotoarinivo, M. \& Dransfield, J. (2010). New species of Dypsis and Ravenea (Arecaceae) from Madagascar. Kew Bull. 65: 279 - 303.

, Dransfield, J., Bachman, S. P., Moat, J. \& Baker, W. J. (2014). Comprehensive red list assessment reveals exceptionally high extinction risk to Madagascar palms. PLoS ONE 9: e106619.

, Trudgen, M. S. \& Baker, W. J. (2009). The palms of the Makira protected area, Madagascar. PALMS 53: $125-146$. 